\title{
Doris Brotz, Michael Weller: Physical therapy for intervertebral disk disease: a practical guide to diagnosis and treatment
}

\section{Thieme Verlag, New York, Stuttgart, Delhi, Rio de Janeiro, 2016, 220 pp, 160 figs., Softcover (KT), with e-book, EUR (D) 59,99 EUR (A) 61,70 CHF 69,00, ISBN: 978-3-13-199761-6}

\section{Pierre Kehr ${ }^{1}$}

Received: 6 May 2018 / Accepted: 20 May 2018 / Published online: 4 June 2018

(c) Springer-Verlag France SAS, part of Springer Nature 2018

This book of rehabilitation and physical treatments is intended to the rehabilitation doctors and to the kinesitherapists. It is dedicated to the pathology of the intervertebral disks of the lumbar spine, the thoracic and the cervical spine. Each segment is studied with diagnosis of assessment, with the diagnostic tests and the therapeutic procedures, with a specific chapter for the patients in postoperative rehabilitation.
Very perfectly illustrated, it will also interest the orthopedic surgeon and the neurosurgeon to know the treatments pre and postoperative their patients.

\section{Compliance with ethical standards}

Conflict of interest The author declares that he has no competing interests. 